
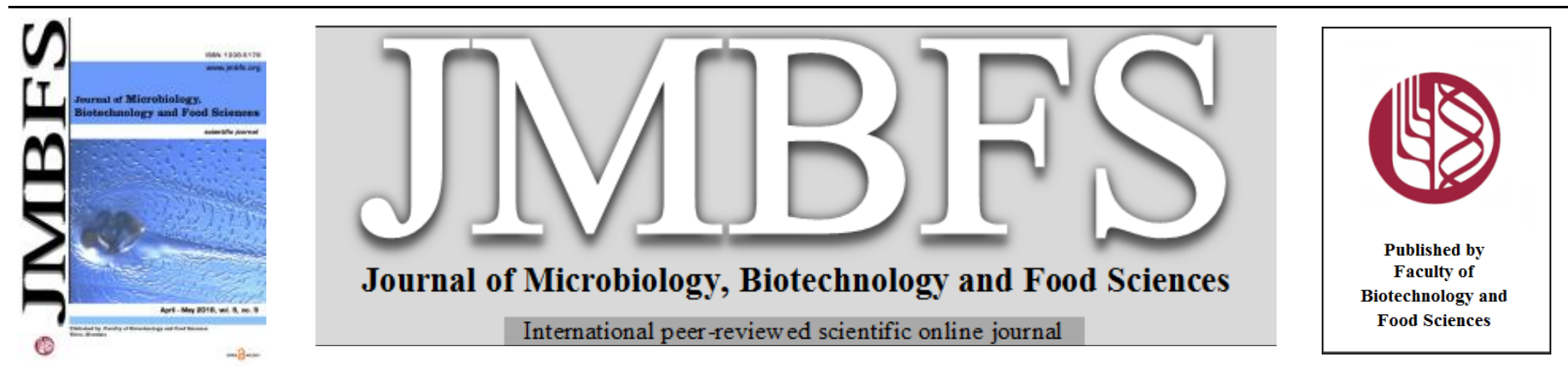

\title{
EVALUATION OF ANTIOXIDANT ACTIVITY, TOXICITY AND ANTIBACTERIAL POTENTIAL OF EXTRACTS OF SENSEVIERIA AETHIOPICA (THUNB) AGAINST BACTERIA ASSOCIATED WITH OTITIS
}

\author{
Oluwole Moses David*1, Jide Anthony Afolayan ${ }^{2}$ \\ Address(es): Oluwole Moses David, \\ ${ }^{1}$ Department of Microbiology, Ekiti State University, Ado-Ekiti, Nigeria. \\ ${ }^{2}$ Phytomedicine Research Centre, Department of Botany, University of Fort Hare, Alice, 5700, South Africa.
}

*Corresponding author: davidoluwole5@gmail.com

doi: 10.15414/jmbfs.2016.5.5.445-449

\section{ARTICLE INFO}

Received 22. 10. 2015

Revised 26. 11. 2015

Accepted 17. 12. 2015

Published 1. 4. 2016

Regular article

OPEN $\partial_{\text {ACCESS }}$

\begin{abstract}
Otitis is highly prevalent infection caused mainly by bacteria and frequently prone to secondary infections. It may lead to other permanent dysfunctions in children and multidrug-resistance has been reported among implicated bacterial pathogens. The aim of this study is to evaluate the phytochemicals, antioxidants and antibacterial potential of acetone and methanolic extracts of Sansevieria aethiopica (Thunb.) leaf against bacterial pathogens responsible for otitis. The phytochemical analyses of the extracts were determined using standard assay methods and the antioxidant activity was assessed using 2,2'-azino-bis-3-ethylbenzothiazoline-6-sulfonic-acid (ABTS), 1,1-diphenyl-2-picrylhydrazyl (DPPH), hydrogen peroxide $\left(\mathrm{H}_{2} \mathrm{O}_{2}\right)$ and ferric reducing power. Brine shrimp lethality test was used to determine the cytotoxicity effect of the extract while macrobroth dilution method was used for the determination of minimal inhibitory concentrations (MICs) of the extracts. The phenolic contents of the extracts were 57.13 and $19.06 \mathrm{mg}$ tannic acid/g in acetone and methanolic extracts respectively. Flavonols and proathocyanidin recorded the least values in methanolic and acetone extracts respectively. The extracts have good antioxidant properties although lower than the standard chemicals used as controls. The extracts expressed antibacterial effects on both Gram negative and Gram positive bacteria however, their activity was more pronounced on Gram negative organisms. Although, slightly toxic, the extracts have both bacteriostatic and bactericidal effects on the selected bacteria associated with otitis, especially Gram negative.
\end{abstract}

Keywords: Otitis, Sensevieria aethiopica, antioxidant, phytochemicals, antibacterial

\section{INTRODUCTION}

Otitis (ear infection) is a spectrum of infections of the ear usually associated with microbial infections of macerated skin and subcutaneous cellular tissue (Aneja $\boldsymbol{e} t$ al., 2010). It is more common in children than adults, approximately $75 \%$ of children experience at least three or more ear infections during the first three years of life (Gates, 1996). Acute otitis is one of the most common childhood infections and is the leading indication for prescription of antimicrobials in children and it is highly prevalent worldwide (Ifante and Fernandez, 1993) Over $50 \%$ of the cases of otitis are caused by bacteria and it has been reported to be the most common infection in young children (Gunnsteinn, 2004), with the average toddlers having two to three episodes a year (Richard and Roberts, 1996) and with mortality rate of more than 50,000 children (under 5 years) per year (Rovers et al., 2006a). Children below the age of seven are much more susceptible to otitis media (Weiner and Collison, 2003).

Ear infection is mainly caused by bacteria and fungal pathogens (Roland and Stroman, 2002). Antimicrobial resistance in these pathogens has become widespread and highly prevalent globally (Doern et al., 2001). This has led to treatment failures which have become more frequent (Kristinsson et al., 2005). Otitis is frequently associated with secondary bacterial and/or fungal infections (Hungria, 1991). The clinical manifestations of otitis include pain, pruritus and erythema also as the disease progresses, edema, otorrhea and conductive hearing loss may also develop (Damoiseaux, 2005). In childhood it leads to significant hearing loss in pediatric patients, resulting in developmental problems in speech, language, and the acquisition of social skills (Bluestone and Klein, 1988; Topcuoglu et al., 2012). Acute cases of bacterial otitis does not only come with earache but also severe pain, fever $\left(39{ }^{\circ} \mathrm{C}\right.$ or more) and febrile seizures (Damoiseaux et al., 2000; Damoiseaux, 2005; Rovers et al., 2006b).

Indiscriminate use of commercial antimicrobial drugs has led to the development of multiple drug resistant strains of bacteria and fungi. This on the other hand informs the search for new antimicrobials from natural sources (Fagbohun et al., 2010). The use of medicinal plants, especially in public health care programs in developing countries is gaining recognized globally. Sansevieria is a genus of xerophytic perennial herbs that occur mostly in dry tropical and subtropical habitats. About 70 species are known with a distribution range from Africa, Asia to Burma and the islands of the Indian Ocean (Purseglove, 1972; Alfani et al., 1989).

Sansevieria aethiopica (Thunb.) is a species of the genus Sansevieria in the family Asparagaceae. It grows as a perennial, stemless, succulent plant with about 1 centimeter thick rhizomes. The 13-30 and succulent rosettes arranged closely together standing leaves are spread out in ascending order. The concave upper surface and the base sometimes narrowed easily (Mansfeld, 2012). $S$. aethiopica is commonly found in Kenya and southern Africa. In South Africa it is found in the provinces of Northern Cape, North West, Eastern Cape and Gauteng spread to dry, open places or in the bush on permeable soils (Hutchings et al., 1996; Newton, 2001) where it is used for the treatment of ear infections, dental caries and ulcers (Hutchings et al., 1996)

The aim of this study is to evaluate the antioxidant activity, toxicity and antibacterial potential of acetone and methanolic leaf extracts of S. aethiopica against bacterial pathogens responsible for otitis.

\section{MATERIALS AND METHODS}

\section{Plant material}

Fresh leaves of S. aethiopica were collected in February, 2012, at the Alice Township in Nkokobe Municipality, Eastern Cape Province (32 58'58'S, $26^{\circ} 54^{\prime} 28^{\prime \prime}$ E and Altitude $589 \mathrm{~m}$ ). The plant was identified in the Department of Botany, University of Fort Hare, Alice, Eastern Cape, South Africa. A voucher specimen (DavMed, 2012/2) was prepared and deposited in the Giffen Herbarium of the University. Plant sample was dried in the oven at the temperature $\left(40^{\circ} \mathrm{C}\right)$.

The dried plant sample was pulverized and $40 \mathrm{~g}$ was separately extracted in acetone and methanol for $48 \mathrm{~h}$ on an orbital shaker (Stuart Scientific Orbital Shaker, Greater Manchester UK). The extracts were filtered through Whatman No. 1 filter paper. The extracts were evaporated to dryness under reduced 
pressure at $40^{\circ} \mathrm{C}$ using a rotary evaporator (Laborota 4000 -efficient, Heldolph, Germany). The extract of the plant was kept in the refrigerator until used.

\section{Phytochemical screening of the plant}

\section{Determination of total phenolics content}

The total phenolics content of the extract were determined by Folin-Ciocalteu method described by Wolfe et al. (2003) with little modification. To $5.0 \mathrm{ml}$ of plant extract with concentration of $0.1 \mathrm{mg} / \mathrm{mL}, 5.0 \mathrm{~mL}$ of $10 \%$ Folin-Ciocalteu reagent and $4.0 \mathrm{~mL}$ of sodium carbonate $(75 \% \mathrm{w} / \mathrm{v})$ was added. The mixture was vortexed for $15 \mathrm{~s}$ and incubated at $40{ }^{\circ} \mathrm{C}$ for $30 \mathrm{~min}$ for colour appearance. The absorbance was measured at $765 \mathrm{~nm}$ using spectrophotometer. Samples of the extract were evaluated at the final concentration of $0.1 \mathrm{mg} / \mathrm{mL}$. The amount of total phenolic content was expressed as $\mathrm{mg} / \mathrm{g}$ tannic acid equivalent using the expression obtained from the calibration curve: $\mathrm{Y}=0.1231 \mathrm{x}, \mathrm{R}^{2}=0.9742$, where $\mathrm{x}$ is the absorbance and $\mathrm{Y}$ is the tannic acid equivalent in $\mathrm{mg} / \mathrm{g}$.

\section{Determination of total flavonoids content}

The total flavonoids were determined using the method of Ordonez et al. (2006) A volume of $0.5 \mathrm{~mL}$ of $2 \% \mathrm{AlCl}_{3}$ ethanol solution was added to $0.5 \mathrm{~mL}$ of extract solution. The mixture was incubated for $1 \mathrm{~h}$ at room temperature for yellow color appearance; the absorbance was measured at $420 \mathrm{~nm}$. Plant extracts were evaluated at a final concentration of $0.1 \mathrm{mg} / \mathrm{mL}$. Total flavonoids content was calculated as quercetin equivalent $(\mathrm{mg} / \mathrm{g})$ using the equation obtained from the curve: $\mathrm{Y}=0.0263 \mathrm{x}, \mathrm{R}^{2}=0.9701$, where $\mathrm{x}$ is the absorbance and $\mathrm{Y}$ is the quercetin equivalent.

\section{Determination of total flavonols content}

The total flavonols content were determined using the method of Kumaran and Karunakaran (2007). Two milliliter $(2.0 \mathrm{~mL})$ of the sample was mixed with 2.0 $\mathrm{mL}$ of $\mathrm{AlCl}_{3}$ prepared in ethanol and $3.0 \mathrm{~mL}$ of $50 \mathrm{~g} / \mathrm{L}$ sodium acetate solution were added. The mixture was incubated at $20{ }^{\circ} \mathrm{C}$ for $2.5 \mathrm{~h}$ after which the absorption was read at $440 \mathrm{~nm}$ using spectrophotometer. Plant extracts were evaluated at a final concentration of $0.1 \mathrm{mg} / \mathrm{mL}$. Total flavonoids contents were calculated as quercetin $(\mathrm{mg} / \mathrm{g})$ using the following equation based on the calibration curve $\mathrm{Y}=0.0263 \mathrm{x}, \mathrm{R}^{2}=0.9824$, where $\mathrm{x}$ is the absorbance and $\mathrm{Y}$ is the quercetin equivalent.

\section{Determination of proanthocyanidins content}

The total proanthocyanidin were determined using the procedure reported by Sun et al. (1998). A volume of $0.5 \mathrm{~mL}$ of $0.1 \mathrm{mg} / \mathrm{mL}$ of extract solution was mixed with $3.0 \mathrm{~mL}$ of $4 \%$ vanillin-methanol solution and $1.5 \mathrm{~mL}$ hydrochloric acid, the mixture was allowed to stand for $15 \mathrm{~min}$ at room temperature, the absorbance was measured at $500 \mathrm{~nm}$. Total proanthocyanidin contents were expressed as catechin $(\mathrm{mg} / \mathrm{g})$ using the following equation of the curve: $\mathrm{Y}=0.5902 \mathrm{x}, \mathrm{R}^{2}=$ 0.9714 , where $\mathrm{x}$ is the absorbance and $\mathrm{Y}$ is the catechin equivalent.

\section{Antioxidant screening of the extract}

\section{ABTS radical scavenging activity}

The method of Re et al. (1999) was adopted for the determination of ABTS activity of the plant extract. The working solution was prepared by mixing two stock solutions of $7 \mathrm{mM}$ ABTS and $2.4 \mathrm{mM}$ potassium persulphate in equal amounts and allowed to react for $12 \mathrm{~h}$ at room temperature in the dark. The resulting solution was further diluted by mixing $1 \mathrm{ml}$ of freshly prepared ABTS solution to obtain an absorbance of $0.706 \pm 0.001$ units at $734 \mathrm{~nm}$ after $7 \mathrm{~min}$ using spectrophotometer. The percentage inhibition of $\mathrm{ABTS}^{-+}$by the extract was calculated and compared with that of BHT and rutin using the following equation:

$\mathrm{ABTS}^{-+}$scavenging activity $=\left[\left(\mathrm{A}_{0}-\mathrm{A}_{1}\right) /\left(\mathrm{A}_{0}\right)\right] \times 100$

Where; $\mathrm{A}_{0}$ is the absorbance of $\mathrm{ABTS}^{-+}+$methanol; $\mathrm{A}_{1}$ is the absorbance of $\mathrm{ABTS}^{-+}+$sample extract or standard.

\section{Determination of diphenyl-1-picrylhydrazyl (DPPH) radical scavenging activity}

The method of Liyana-Pathiranan and Shahidi (2005) was adopted for the determination of scavenging activity of DPPH free radical in the solution of the extract. A solution of $0.135 \mathrm{mM}$ DPPH in methanol was prepared and $1.0 \mathrm{ml}$ of this solution was added into $1.0 \mathrm{ml}$ of the extract prepared in methanol with concentrations ranging between 0.025 and $0.400 \mathrm{mg} / \mathrm{ml}$ and standard drugs BHT and Rutin. The reaction mixture was vortexed thoroughly and was left in the dark at room temperature for $30 \mathrm{~min}$. The absorbance of the mixture was measured in the spectrophotometer at $517 \mathrm{~nm}$. The ability of the plant extract to scavenge DPPH radical was calculated by the equation: DPPH radical scavenging activity
$=\left[\left(\mathrm{A}_{0}-\mathrm{A}_{1}\right) /\left(\mathrm{A}_{0}\right)\right] \times 100 ;$ where $\mathrm{A}_{0}$ is the control and $\mathrm{A}_{1}$ is the absorbance of the extract.

\section{Determination of hydrogen peroxide inhibition activity}

The $\mathrm{H}_{2} \mathrm{O}_{2}$ inhibition effect of the extract was determined by the method of Gulcin (2006). A $1.0 \mathrm{ml}$ of the sample was added to a $0.6 \mathrm{ml}$ of $40 \mathrm{mM}$ hydrogen peroxide solution prepared in phosphate buffer $(\mathrm{pH} 7.4)$. The absorbance of the hydrogen peroxide at $230 \mathrm{~nm}$ was determined after $10 \mathrm{~min}$ at room temperature against a blank solution containing phosphate buffer solution alone. BHT and ascorbic acid were used as positive controls. The percentage scavenging of hydrogen peroxide of the samples was calculated as follow

$\mathrm{H}_{2} \mathrm{O}_{2}$ inhibition capacity $(\%)=\left(1-\left(\mathrm{H}_{2} \mathrm{O}_{2}\right.\right.$ concentration of sample $/ \mathrm{H}_{2} \mathrm{O}_{2}$ concentration of control)) $\times 100$.

\section{The ferrous reducing antioxidant power (FRAP) Assay}

The FRAP assay was carried out according to Benzie and Strain (1999) with a slight modification. FRAP reagent solution consisted of $300 \mathrm{mmol} / \mathrm{l}$ acetate buffer (pH 3.6), $10 \mathrm{mmol} / \mathrm{l}$ of 2,4,4-Tri(2-pyridyl)-s-triazine (TPTZ) in 40 $\mathrm{mmol} / \mathrm{l}$ hydrochloric acid, and $20 \mathrm{mmol} / \mathrm{l}$ iron (III)-chloride hexahydrate. The fresh working solution was prepared by mixing $25 \mathrm{ml}$ acetate buffer, $2.5 \mathrm{ml}$ TPTZ, and $2.5 \mathrm{ml} \mathrm{FeCl}_{3} \cdot 6 \mathrm{H}_{2} \mathrm{O}$. The temperature of the solution was raised to 37 ${ }^{\circ} \mathrm{C}$ before using. Plant extracts $(150 \mu \mathrm{L})$ were allowed to react with $2850 \mu \mathrm{L}$ of the FRAP solution for $30 \mathrm{~min}$ in the dark condition. Readings of the colored product (ferrous tripyridyltriazine complex) were taken at $593 \mathrm{~nm}$. The standard curve was linear between 200 and $1000 \mu \mathrm{M}$ FeSO4. Results are expressed in $\mu \mathrm{M}$ $\mathrm{Fe}(\mathrm{II}) / \mathrm{g}$ dry mass and compared with that of BHT, ascorbic acid and catechin.

\section{Brine shrimp lethality test}

Toxicity was studied using the larvae of brine shrimp nauplii, Artemia salina L (Meyer et al., 1982). Shrimp eggs were allowed to hatch and mature as nauplii in two days in a hatching tank filled with seawater. The free-swimming nauplii were attracted by a light to a compartment from which they could be collected for the assay proper. Vials containing 4 to $20 \mu \mathrm{g}$ ml-1 samples were prepared by dissolving the extracts in distilled water and transferring the solution to each vial The crude extract was initially dissolved in dimethyl sulfoxide (DMSO) to make the extracts hydrophilic. Then distilled water was added to get final concentrations. In the control tube the same volume of DMSO and sea water were taken. After $24 \mathrm{~h}$ of exposure the mortality was determined using this formula:

\section{$C_{m}=\left[\left(O_{m}-C_{m}\right) /\left(100-C_{m}\right)\right] \times 100$}

Where $\mathrm{C}_{\mathrm{m}}=$ Corrected mortality, $\mathrm{O}_{\mathrm{m}}=$ Observed mortality, $\mathrm{C}_{\mathrm{m}}=$ Control mortality.

The observed data was the subject to Probit analysis was calculated according to Finney (1974) to get the dose that will kill $50 \%$ of the brine shrimps $\left(\mathrm{LD}_{50}\right)$

\section{Antimicrobial properties of the extract}

\section{Source and standardization of test bacteria}

Eight bacterial isolates were used in this study are Pseudomonas aeruginosa ATCC 19582, Klebsiella pneumoniae ATCC 10031, Enterobacter cloaca ATCC 13047, Esherichia coli ATCC 25922, Bacillus cereus ATCC 10702 Staphylococcus aureus ATCC 6538, Staphylococcus aureus OK1 and Bacillus pumilus ATCC 14884. The isolates were collected from the Department of Biochemistry and Microbiology, University of Fort Hare, Alice. Each of the bacteria was maintained on nutrient agar (Biolab No. 2, Wadeville, Gauteng, South Africa) plates. The grown cultures were used for preparation of bacterial suspensions in sterile distilled water with densities adjusted to 0.5 McFarland Standard. A $0.25 \mathrm{ml}$ of the standardized suspension was added to the $25 \mathrm{ml}$ Mueller Hinton Broth and used for the inoculation of the tubes.

\section{Determination of minimum inhibitory concentration (MIC)}

Macrobroth dilution method was used for the determination of minimal inhibitory concentration (MIC) of the extract as described by CLSI (2012). Nutrient broth medium was used to prepare different concentrations ranging from 0.0977 to 25 $\mathrm{mg} / \mathrm{ml}$ by serial dilutions. Each prepared concentration in tubes was inoculated with $100 \mu \mathrm{l}$ of each of the standardized culture of the test bacteria. Tube containing nutrient agar without extract was used as negative control. The tubes were incubated aerobically at $37^{\circ} \mathrm{C}$ for $18 \mathrm{~h}$. The first tube in the series with no sign of visible growth was taken as the MIC. 


\section{Determination of minimum bactericidal concentration (MBC)}

MBC was determined by taken one standard loopful of culture from each of the first three broth tubes that showed no growth in the MIC tubes and inoculated on fresh nutrient agar plates. After incubation for $24 \mathrm{~h}$, the least concentration of the extracts that showed no colony formation on the agar was taken as the MBC. The ratio of MBC to MIC was determined to predict effect of the extract on the test bacteria. MBC/MIC ratios greater than 1 was considered bacteriostatic while other MBC/MIC ratios were considered bactericidal (Shanmughapriya et al., 2008)

\section{RESULTS AND DISCUSSION}

The phytochemical screening of the extracts of the plant shows that the solvents extracted different components of the plant. The phenolic was 57.13 and 19.06 $\mathrm{mg}$ tannic acid/g in acetone and methanolic extracts respectively. Flavonols and proathocyanidin recorded the least value in methanolic and acetone extract respectively. Apart from flavonoids, acetone extracted other phytochemicals in larger quantity than methanol. The amount of the phenolic in the acetone extract was three times more than that of methanolic as shown in Table 1. Acetone performed better than methanolic in extracting the phytochemicals. Plants play a major roles development of new chemotherapeutic agents. The first step towards this goal is the in vitro antibacterial activity assay. Polyphenols have been reported to be the major plant compounds with antioxidant activity due to their redox properties (Roginsky and Lissi, 2005). They adsorbed, neutralize free radicals and quenching singlet and triplet oxygen (Ilias and Carlos, 2001). Flavonoids have been reported to possess strong antioxidant properties (Diouf $e t$ al., 2009; Oyedemi et al., 2010).

Table 1 Phytochemical analyses of extracts of S. aethiopica leaf

\begin{tabular}{lcc}
\hline \multirow{2}{*}{ Phytochemicals } & \multicolumn{2}{c}{ Extract } \\
\cline { 2 - 3 } & Methanolic & Acetone \\
\hline Phenolic $(\mathrm{mg} / \mathrm{g}) *$ & $19.06 \pm 3.92$ & $57.13 \pm 13.05$ \\
Flavonoids $(\mathrm{mg} / \mathrm{g}) * *$ & $6.84 \pm 2.14$ & $5.92 \pm 1.82$ \\
Flavonols $(\mathrm{mg} / \mathrm{g}) * *$ & $2.78 \pm 0.38$ & $15.20 \pm 4.27$ \\
Proathocyanidin $(\mathrm{mg} / \mathrm{g}) * * *$ & $6.42 \pm 2.74$ & $14.52 \pm 3.11$ \\
\hline
\end{tabular}

Data are expressed as means \pm SD of triplicate determinations; *Expressed as mg tannic $\mathrm{acid} / \mathrm{g}$ of dry plant materials, **Expressed as $\mathrm{mg}$ quercetin/g of dry plant materials and ***Expressed as $\mathrm{mg}$ catechin/g of dry plant material

The rate of ABTS radical scavenging was determined for the two extracts of $S$ aethiopica. The activity of the plant extracts was lower than the phenolic derivative standards: BHT and rutin. As shown in Figure 1, the ABTS radical scavenging activity of the extracts at $0.8 \mathrm{mg} / \mathrm{mL}$ compared with the standard is in the decreasing order: BHT $(94.95 \%)>$ Rutin $(87.52 \%)>$ Acetone extract $(83.07 \%)>$ methanolic extract $(76.79 \%)$. This showed that the plant has good ability to prevent oxidative damages (Benzie and Strain, 1999). ABTS is one of the free radicals that have been used for assessing antioxidant activity (Santos $\boldsymbol{e}$ al., 2003) the extracts were able to mop up free radical generated by loss of electrons and produced a colored nitrogen centered cation by reacting with potassium persulfate for $12-14 \mathrm{~h}$.

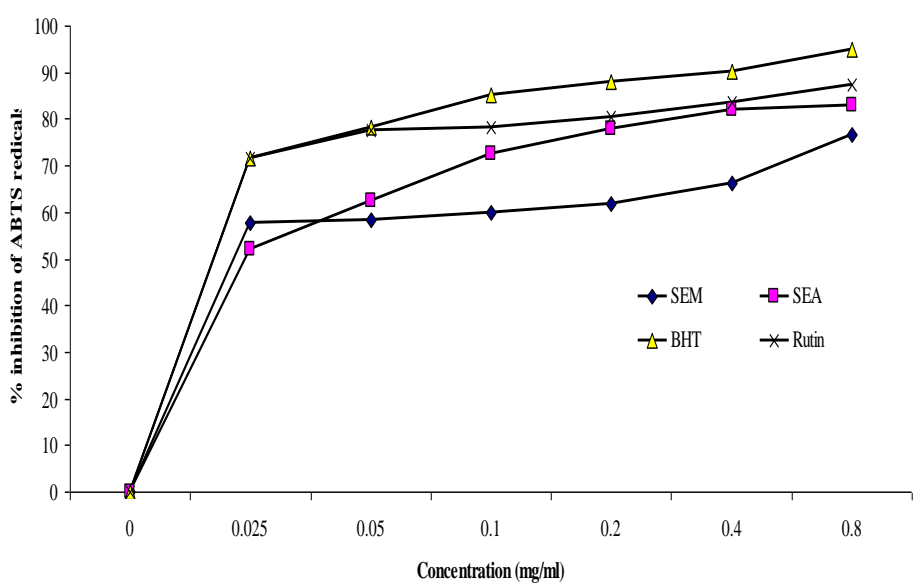

Figure 1 ABTS radical scavenging activity of extracts of $S$. aethiopica leaf

The antioxidant effect of the acetone and methanolic extracts of $S$. aethiopica was analyzed for the scavenging activity on free radical DPPH in a concentration-dependent manner. The maximum scavenging effect exerted by the extract to that exerted by the standards (BTH and Rutin) controls. The activity of the extracts is dose-dependent. The extracts of $S$. aethiopica had a good DPPH scavenging property compared with the control (Figure 2). Therefore, the data obtained from this study justified the ethnomedicinal use of this plant in the treatment of ear infections initiated by oxidative stress (Sharma et al., 2012). At all the concentrations tested methanolic extract performed better than the acetone extract. The antioxidant ability of the extracts to donate hydrogen to DPPH radical, thus converting it into stable molecules is due to the presence of the Phytochemicals like phenolic compounds, such as flavonoid, polyphenol, tannins and terpenes as earlier reported (Zheng and Wang, 2001; Guittat et al., 2003; Sawer et al., 2005). The redox properties by the Phytochemicals play an important role in adsorbing and neutralizing free radicals (Badami et al., 2003). Antioxidant potentials of the extract determined based on the measurement of free radical scavenging potency (hydrogen-donating ability). The radical scavengers donate hydrogen to free radicals. The use of DPPH radical provides an easy, rapid and convenient method to evaluate the antioxidants and radical scavengers (Olorunnisola et al., 2011).

Extracts of $S$. aethiopica showed high level of scavenging ability agains hydrogen peroxide at $0.8 \mathrm{mg} / \mathrm{ml}$ were $62.92,66.78,62.81$ and $82.05 \%$ for methanolic extract, acetone extract, BTH and rutin respectively (Figure 3 ). Except at the final concentration the hydrogen peroxide scavenging activity of the acetone extract was higher than BTH but lower than rutin. Methanolic extract has a lower scavenging activity than the acetone extract. These plant extract will be able to protect cells against the damaging effect of free radicals generated by hydrogen peroxides (Ilias and Carlos, 2001; Oyedemi et al., 2010). Hydrogen peroxide is a highly important reactive oxygen species it has ability to penetrate biological membranes. It may also have a detrimental effect on the cell if it is converted to hydroxyl radical which is toxic to the cell (Larson, 1988; Fukumoto and Mazza, 2000; Gulcin et al., 2003). The acetone extract of $S$ aethiopica was capable of scavenging hydrogen peroxide in a concentration dependent manner.

The ferric reducing/antioxidant power (FRAP) is a non-inhibition and direct test of total antioxidant power method of determining antioxidant potency of biological substances (Benzie and Strain, 1999). FRAP assay is simple, speedy and robust assay (Prior et al., 2005). It is regarded as a direct test of total antioxidant power. It treats both chemically defined reductant and biologically defined antioxidants as basically equal. In the present study, the highest antioxidant potential was observed in Vitamin $\mathrm{C}$ followed by the two the other standard chemicals: Vitamin E and BHT (in decreasing order) (Figure 4). The extracts performance was relatively poor. Acetone extract was better than the methanolic extract at all the concentrations tested. The reducing power of the extract showed to be concentration dependent. The FRAP assay involves neither a pro-oxidant nor an oxidizable substrate. It depends upon the reduction of a ferric tripyridyltriazine complex to the ferrous tripyridyltriazine by a reductant at low pH (Benzie and Strain, 1999).

Brine shrimp is a low cost bench bioassay indicative of toxicity to different biological and chemical agents. The plant extracts had lethal effects on the brine shrimp nauplii with $\mathrm{LD}_{50}$ of 3.17 and $3.71 \mathrm{ppm}$ for acetone and methanolic extracts respectively as shown in Figure 5. The extracts were classified as toxic to Artemia salina at the observed $\mathrm{LC}_{50} \mathrm{~s}$. The $\mathrm{LC}_{50} \mathrm{~S}$ of the extracts were higher than standard limit (1ppm) (Prior et al., 2005). The extracts could be termed considerably toxic.

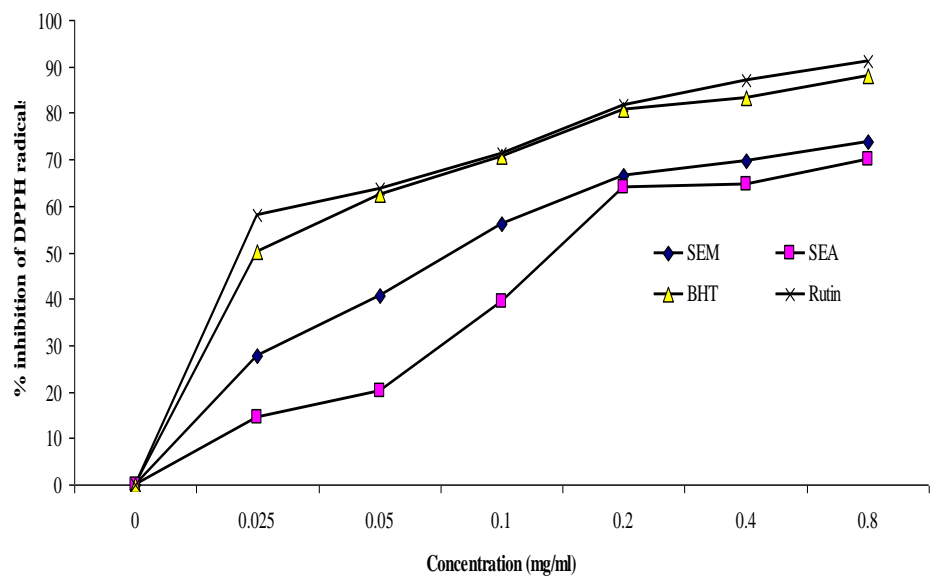

Figure 2 DPPH radical scavenging activity of acetone extract of S. aethiopica leaf 


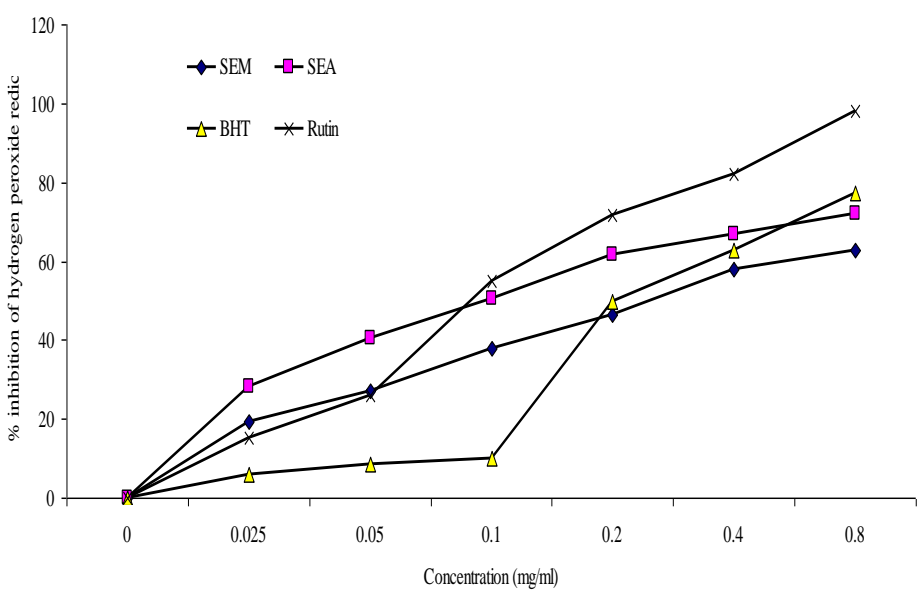

Figure 3 Hydrogen peroxide radical scavenging activity of extracts of $S$. aethiopica leaf

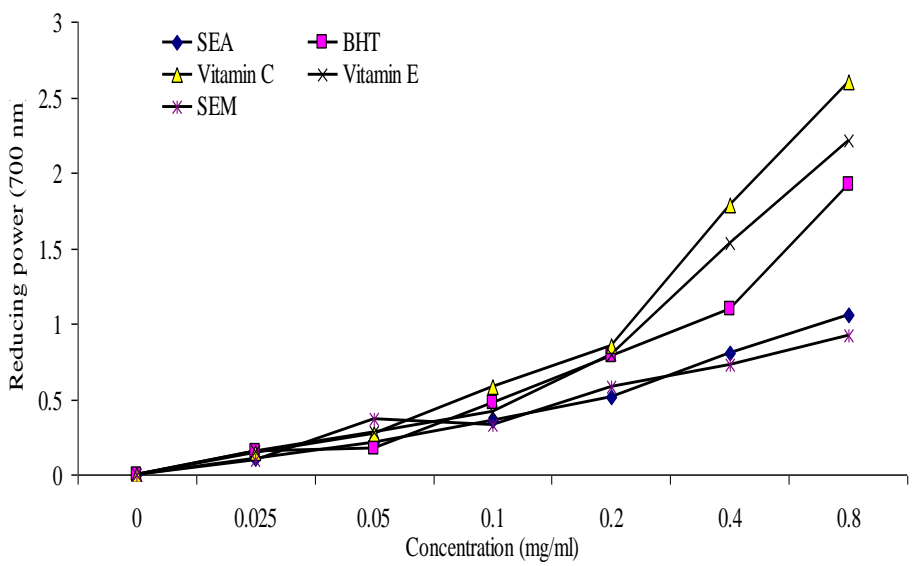

Fig. 5: Figure 4 Reducing power activities of extracts of S. aethiopica leaf

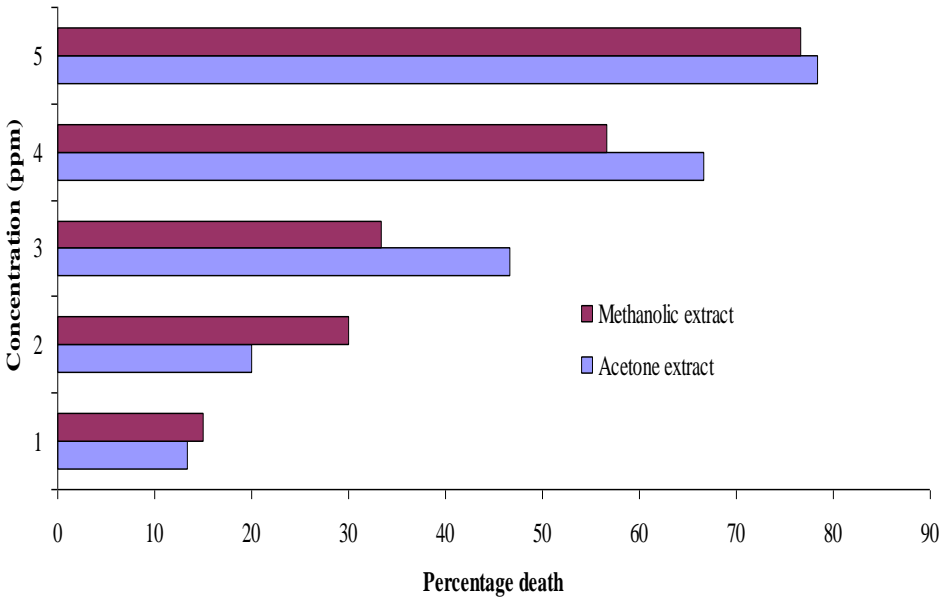

Figure 5 Brine shrimp cytotoxicity of extracts of S. aethiopica leaf

The result of the antibacterial assay showed that the extracts had good antibacterial activity against both Gram-positive and Gram-negative bacteria. The MIC and MBC values varied among the tested otitis bacterial pathogens. The susceptibility of all these bacteria to the extracts showed that Gram negative bacteria were relatively more susceptible to the extracts than Gram positive bacteria. This report contradicts the report of Sharma and colleagues (Sharma $e$ al., 2012) that reported Gram negative bacteria pathogens associated with ear infections to be more resistant to plant extracts than Gram positives. Since different plants possess varying phytochemicals and these phytochemicals have different mechanisms of actions against pathogens (Guittat et al., 2003). Antimicrobial actions of the extract may not be targeted against the cell wall that makes a gram negative pathogen to be more resistant to most antimicrobials as earlier reported. It may be as a result of DNA intercalator and an inhibitor of DNA synthesis through topoisomerase inhibition (Lisgarten et al., 2002; Guittat et al., 2003). For the Gram negative bacteria the highest MIC was recorded against $P$. aeruginosa ATCC 19582: 3.125 and $1.5625 \mathrm{mg} / \mathrm{ml}$ for acetone and methanolic extracts respectively. The resistance of this pathogen may be as a result of their chemical composition and their ability to form spores. The MIC index however, and expectedly, suggested that the plant extract was bacteriostatic at lower concentration and bactericidal at higher concentration.

Table 2 Antibacterial activity of extracts of S. aethiopica leaf against bacteria associated with otitis

\begin{tabular}{|c|c|c|c|c|c|c|c|}
\hline \multirow{3}{*}{ Pathogens } & \multirow{3}{*}{$\begin{array}{l}\text { Gram } \\
\text { Reaction }\end{array}$} & \multicolumn{6}{|c|}{ Extracts } \\
\hline & & \multicolumn{3}{|c|}{ Acetone } & \multicolumn{3}{|c|}{ Methanol } \\
\hline & & MIC & MBC & MBC/MIC & MIC & MBC & MBC/MIC \\
\hline P. aeruginosa ATCC 19582 & -ve & 3.125 & 6.25 & 2.0 & 1.5625 & 12.5 & 8.0 \\
\hline K. pneumoniae ATCC 10031 & -ve & 0.3906 & 3.125 & 8.0 & 0.7812 & 3.125 & 4.0 \\
\hline Ent. cloaca ATCC 13047 & -ve & 0.7812 & 0.7812 & 1.0 & 0.7812 & 0.7812 & 1.0 \\
\hline E. coli ATCC 25922 & -ve & 0.7812 & 3.125 & 4.0 & 1.5625 & 1.5625 & 1.0 \\
\hline B. cereus ATCC 10702 & $+\mathrm{ve}$ & 1.5625 & 3.125 & 2.0 & 3.125 & 6.25 & 2.0 \\
\hline S. aureus ATCC 6538 & +ve & 3.125 & 3.125 & 10.0 & 1.5625 & 3.125 & 2.0 \\
\hline S. aureus $\mathrm{OK} 1$ & + ve & 1.5625 & 3.125 & 2.0 & 0.7812 & 6.25 & 8.0 \\
\hline B. pumilus ATCC 14884 & $+\mathrm{ve}$ & 3.125 & 6.25 & 2.0 & 1.5625 & 3.125 & 2.0 \\
\hline
\end{tabular}

\section{CONCLUSION}

The extracts of $S$. aethiopica (Thunb.) compared with the standard chemicals is very rich in phytochemicals and antioxidant properties. It also showed good antibacterial activity on both Gram negative and Gram positive bacteria although, the effects was more pronounced on Gram negative. This work serves as basic scientific validation of the folkloric uses of the plant for the treatment of ear infection in South Africa. The extract will certainly contain bioactive compounds that could be good candidates for the treatment of drug-resistant ear bacteria pathogens.

Acknowledgments: The authors wish to acknowledge the financial support of the National Research Foundation and the University of Fort Hare, South Africa.

\section{REFERENCES}

ALFANI, A., LIGRONE, R., FIORETTO, A., VIRZO, D. E., SANTO, A. 1989 Histochemistry, ultrastructure and possible significance of dead parenchyma cells with specialised walls in the leaf and rhizome of Sansevieria. Plant Cell and Environment, 12, 249-259. http://dx.doi.org/10.1111/j.1365-3040.1989.tb01939.
ANEJA, K. R., SHARMA, C., JOSHI, R. 2010. Fungal infection of the ear: a common problem in the north eastern part of Haryana. International Journal of $\begin{array}{lll}\text { Pediatric } & \text { Otorhinolaryngology, } & \end{array}$ http://dx.doi.org/10.1016/j.ijporl.2010.03.001.

BADAMI, S., GUPTA, M. K., SURESH, B. 2003. Antioxidant activity of the ethanolic extract of Striga orobanchioides. Journal of Ethnopharmacology, 85, 227-230. http://dx.doi.org/10.1016/S0378-8741(03)00021-7.

BENZIE, I. F. F., STRAIN, J. J. 1999. Ferric reducing/antioxidant power assay: direct measure of total antioxidant activity of biological fluids and modified version for simultaneous measurement of total antioxidant power and ascorbic acid concentration. Methods in Enzymology, 299, 15-27. http://dx.doi.org/10.1016/S0076-6879(99)99005-5.

BLUESTONE, C. D., KLEIN, J. O. 1988. Otitis media in infants and children. Philadelphia: WB Saunders Company, 1988.

CLSI. 2012. Performance standards for antimicrobial susceptibility testing. $15^{\text {th }}$ informational supplement. Wayne, PA: Clinical and Laboratory Standards Institute; M100-S15.

DAMOISEAUX, R., BALEN, F., HOES, A., VERHEIJ, T., DE MELKER, R. 2000. Primary care based randomised, double blind trial of amoxicillin for acute otitis media in children aged under 2 years. British Medical Journal, 320(7231), 350-354. 
DAMOISEAUX, R. 2005. Antibiotics treatment for acute otitis media: time to think again" America Medical Journal, 172(5), 648 - 657. http://dx.doi.org/10.1503/cmaj.050078.

DIOUF, P. N., STEVANOVIC, T., CLOUTIER, A. 2009. Study on chemical composition and anti-inflammatory activities of hot water extract Piceamariana bark and its proanthocyanidin-rich fractions. Food Chemistry, 113, 897-902. http://dx.doi.org/10.1016/j.foodchem.2008.08.016.

DOERN, G. V., HEILMANN, K. P., HUYNH, H. K., RHOMBERG, P. R., COFFMAN, S. L., BRUEGGEMANN, A. B. 2001. Antimicrobial resistance among clinical isolates of Streptococcus pneumoniae in the United States during 1999-2000, including a comparison of resistance rates since 1994-1995. Antimicrobial Agents and Chemotherapy, 45, 1721-1729. http://dx.doi.org/10.1128/AAC.45.6.1721-1729.2001.

FAGBOHUN, E. D., DAVID, O. M., ADEYEYE, E. I., OYEDELE, O. 2010 Chemical composition and antibacterial activities of some selected traditional medicinal plants used in the treatment of gastrointestinal infections in Nigeria. International Journal of Pharmaceutical Sciences Review and Research, 5(3), 192-197.

FINNEY, D. J. 1974. Probit Analysis: A Statistical Treatment of the Sigmoid Response Curve, p: 333. Cambridge University Press, London.

FUKUMOTO, L. R., MAZZA, G. 2000. Assessing antioxidant and prooxidant activities of phenolic compounds. Journal of Agriculture and Food Chemistry, 48, 3597-3604. http://dx.doi.org/10.1021/jf000220w.

GATES, G. A. 1996. Cost-effectivess consideration of otitis media treatment

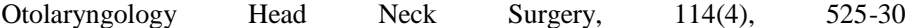
http://dx.doi.org/10.1016/S0194-5998(96)70243-7.

GUITTAT, L., ALBERTI, P., ROSU, F., VAN MIERT, S., THETIOT, E., PIETERS, L., GABELICA, V., DE PAUW, E., OTTAVIANI, A., ROIU, J. F., MERGNY, J. L. 2003. Interaction of cryptolepine and neocryptolepine with unusual DNA structures. Biochnology, 85, 535-541.

GULCIN, I., OKTAY, M., KIRECCI, E., KUFREVIOGLU, O. I. 2003. Screening of antioxidant and antimicrobial activities of anise (Pimpinella anisum L) seed extracts. Food Chemistry, 83, 371-382. http://dx.doi.org/10.1016/S03088146(03)00098-0.

GULCIN, I. 2006. Antioxidant activity of caffeic acid (3,4-dihydroxycinnamic acid). Toxicology, 217, 213-220.

GUNNSTEINN, H. W., PETER, H., EIJA, K. 2004. Clonal similarity of salivary and nasopharyngeal Fusobacterium nucleatum in infants with acute otitis media experience. Journal of Medical Microbiology, 53, 161-165. http://dx.doi.org/10.1099/jmm.0.05441-0.

HUNGRIA, H. 1991. Otorrinolaringology. 6. ed. Rio de Janeiro: Guanabara Koogan, cap. 34, pp.297-301.

HUTCHINGS, A., SCOTT, A. H., LEWIS, G., CUNNINGHAM, A. B. 1996 Zulu Medicinal Plants - An Inventory. University of Natal Press, Pietermaritzburg, South Africa.

IFANTE, R. C., FERNANDEZ, A. 1993. Otitis media in children: frequency, risk factors and research avenues. Epidemiology Review, 15, 446-465.

ILIAS, G. K., CARLOS, T. M. 2001. Reactive oxygen species and mitochondrial diseases. Cell Development Biology, 12, 449-457.

KRISTINSSON, K. G., MAGNUSDOTTIR, A. B., PETERSEN, H. HERMANSSON, A. 2005. Effective treatment of experimental acute otitis media by application of volatile fluids into the ear canal. The Journal of Infectious Diseases, 191,1876-1880. http://dx.doi.org/10.1016/j.lwt.2005.09.011.

KUMARAN, A, KARUNAKARAN, R. J. 2007. In vitro antioxidant activities of methanol extracts of Phyllantus species from India. Lebensmittel- Wissenschaft and Technology. 40: 344-352.

LARSON, R. A. 1988. The antioxidants of higher plants. Phytochemistry, 27, 969-978. http://dx.doi.org/10.1016/0031-9422(88)80254-1

LISGARTEN, J. N., COLL, M., PORTUGAL, J., WRIGHT, C. W, AYMAMI, J. 2002. The antimalarial and cytotoxic drug cryptolepine intercalates into DNA at cytosine-cytosine sites. Nature Structural Biology, 9, 57-60. http://dx.doi.org/10.1038/nsb729.

LIYANA-PATHIRANAN, C. M., SHAHIDI, F. 2005. Antioxidant activity of commercial soft and hard wheat (Triticum aestivum $\mathrm{L}$ ) as affected by gastric $\mathrm{pH}$ conditions. Journal of Agriculture and Food Chemistry, 53, 2433-2440. http://dx.doi.org/10.1021/jf049320i.

MANSFELD, P. A. 2012. About Sansevieria - Manual on origin, cultivation and care. 1st Edition. BoD, Hamburg, pp. 38-39.

MEYER, B. N., FERRINGNI, N. R., PUTNUM, J. E., JACOBSON, L. B. NICHOLLAS, D. E., MCLAUGHLIN, J. L. 1982. Brine shrimp: a convenient general bioassay for active plant constituents. Plant Medicine, 45, 31-34 http://dx.doi.org/10.1055/s-2007-971236.

NEWTON, L. E. 2001. Sansevieria. In: UrsEggli (ed.): Succulents Encyclopedia Volume 1 monocots plants (monocots), Eugen Ulmer, Stuttgart, p 272.

OLORUNNISOLA, O. S., BRADLEY, G., AFOLAYAN, A. J. 2011. Antioxidant properties and cytotoxicity evaluation of methanolic extract of dried and fresh rhizomes of Tulbaghia violacea. Africa Journal of Pharmacy and Pharmacology, 5(22), 2490-2497. http://dx.doi.org/10.5897/AJPP11.620.

ORDONEZ, A. A. L., GOMEZ, J. D., VATTUONE, M. A., ISLA, M. I. 2006 Antioxidant activities of Sechium edule (Jacq). Food Chemistry, 97, 452-458.
OYEDEMI, S. O., BRADLEY, G., AFOLAYAN, A. J. 2010. In vivo and in vitro antioxidant activities of aqueous stem bark extract of Strychnos henningsii (Gilg). Africa Journal of Pharmacy and Pharmacology, 4, 70-78.

PRIOR, R. L., WU, X., SCHAICH, K. 2005. Standardized methods for the determination of antioxidant capacity and phenolics in foods and dietary supplements. Journal of Agriculture and Food Chemistry, 53, 4290-4302. http://dx.doi.org/10.1021/jf0502698.

PURSEGLOVE, J. W. 1972. Tropical Crops: Monocotyledons. Volume 1. Longman, London. 1972.

RE, R., PELlegrini, N., PROTEGGENTE, A., PANNAla, A., YANG, M., RICE-EVANS, C. 1999. Antioxidant activity applying an improved ABTS radical cation decolorization assay. Free Radical Biology and Medicine, 26 , 1231-1237. http://dx.doi.org/10.1016/S0891-5849(98)00315-3.

RICHARD, E. B., ROBERTS, M. K. 1996. Otitis Media and its complication. In: Nelson's Textbook of Paediatrics, pp. 1814-1824,

ROGINSKY, V., LISSI, E. A. 2005. Review of methods to determine chainbreaking antioxidant activity in food. Food Chemistry, 92, 235-254, 2005.

ROLAND, P. S., STROMAN, D. W. 2002. Microbiology of acute otitis externa Larygoscope, $112(7$ Pt 1): 166-177. http://dx.doi.org/10.1097/00005537$200207000-00005$.

ROVERS, M. M., DE KOK, I. M., SCHILDER, A. G. M. 2006a. Risk factors for otitis media: An international perspective. International Journal of Pediatrics, 70, 1251-1256. http://dx.doi.org/10.1016/j.ijporl.2006.01.003.

ROVERS, M. M., GLASZIOU, P., APPELMAN, C. L., BURKE, P., DAMOISEAUX, R. A., HOES, A. W. 2006b. Antibiotics for acute otitis media: A meta-analysis with individual patient data". Lancet, 368 (9545), 1429-1435. http://dx.doi.org/10.1016/S0140-6736(06)69606-2.

SANTOS, L. P., PINTO, G. B., TAKAHASHI, J. A., SILVA, L. G. BOAVENTURA, M. A. Biological screening of Annonaceous Brazilian medicinal plants using Artemia salina (Brine Shrimp Test). Phytomedicine, 10, 209-212. http://dx.doi.org/10.1078/094471103321659960.

SAWER, I. K., BERRY, M. I., FORD, J. L. 2005. The killing effect on Staphylococcus aureus. Letter in Applied Microbiology, 40, 24-29. http://dx.doi.org/10.1111/j.1472-765X.2004.01625.

SHANMUGHAPRIYA, S. A., MANILAL, A., SUJITH, S., SELVIN, J., KIRAN, G. S. NATARAJASEENIVASAN, K. 2008. Antimicrobial activity of seaweeds extracts against multi-resistant pathogens. Annals of Microbiology, 58, 535-541. http://dx.doi.org/10.1007/BF03175554.

SHARMA, C., ANEJA, K. R., KASERA, R., ANEJA, A. 2012. Antimicrobial potential of Terminalia chebula Retz . fruit extracts against ear pathogens. World Journal of Otorhinolaryngology, 2(2), 8 -13.

SOLER-RIVAS, C., ESPIN, J. C., WICHERS, H. J. 2000. An easy and fast test to compare total free radical scavenger capacity of foodstuffs. Phytochemical http.//dx doi org/10 1002/10991565(200009/10)11:5<330::AID-PCA534>3.0.CO;2-G.

SUN, J. S. TSUANG, Y. W., CHEN, J. J, HUANG, W. C., HANG, Y. S., LU, F J. 1998. An ultra-weak chemiluminescence study on oxidative stress in rabbits following acute thermal injury. Burns, 24, 225-231. http://dx.doi.org/10.1016/S0305-4179(97)00115-0.

TOPCUOGLU, N., KESKIN, F., CIFTCI, S., PALTURA, C., KULEKCI, M. USTEK, D., KULEKCI, G. 2012. Relationship between oral anaerobic bacteria and otitis media with effusion. International Journal of. Medical Science, 9(3), 256-261. http://dx.doi.org/10.7150/ijms.4382.

WEINER, R., COLLISON, P. J. 2003. middle ear pathogens in otitis prone children. South Dakota Journal of Medicine, 56, 103-107.

WOLFE, K., WU, X., LIU, R. H. 2003. Antioxidant activity of apple peels Journal of Agriculture and Food Chemistry, 51, 609-614. http://dx.doi.org/10.1021/jf020782a.

ZHENG, W. WANG, S. Y. 2001. Antioxidant activity and phenolic compounds in selected herbs. Journal of Agriculture and Food Chemistry, 49, 5165-5170. http://dx.doi.org/10.1021/jf010697n. 